\title{
Ostvarenost ishoda učenja biologije u sustavu e-učenja
}

\author{
Mila Bulić \\ ${ }^{1}$ Filozofski fakultet Sveučilišta u Splitu, Poljička cesta 35, 21000 Split, Republika Hrvatska \\ mbulic@ffst.hr
}

\begin{abstract}
SAŽETAK
U kontekstu globalnih društvenih promjena u sustavu odgoja i obrazovanja važno je mijenjati pristup stjecanja temeljnih kompetencija učenika s posebnim naglaskom na razvoj njihove prirodoslovne i digitalne pismenosti. Današnje učenike, pripadnike allways on line generacije, karakterizira intenzivno korištenje Interneta za socijalne interakcije, ali i za obrazovanje. Upravo stoga potrebno je implementirati IKT-u u nastavnu praksu, a jedna od mogućnosti je e-učenje. S ciljem istraživanja ostvarenosti ishoda učenja prema kognitivnim razinama zadataka obzirom na primijenjene postupke poučavanja i učenja, tradicionalnu nastavu i e-učenje, provedeno je istraživanje u nastavi Prirode i Biologije osnovne škole na uzorku od osam razrednih odjela. Rezultati istraživanja pokazuju podjednaku uspješnost učenika eksperimentalne i kontrolne skupine u ostvarenosti ishoda učenja te se e-učenje pokazalo jednako uspješnijim kao i tradicionalna nastava u kojoj su korištene suvremene nastavne strategije rada. Stoga se e-učenje može koristiti i u situacijama, poput bolesti, odlaska učenika na višednevna natjecanja, života u izdvojenim sredinama, kada ne postoji mogućnost da učenici nazoče redovnoj nastavi. Istraživanje je pokazalo kako učenici kontrolne i eksperimentalne skupine jednako uspješno/neuspješno rješavaju zadatke prve, druge i treće kognitivne razine. Dobiveni rezultati mogu poslužiti kreatorima obrazovne politike te biti smjernica učiteljima praktičarima za oblikovanje nastave.
\end{abstract}

Ključne riječi: e-učenje; IKT u nastavi; kognitivne razine; nastava Prirode i Biologije

\section{UVOD}

Suvremeno društvo obilježavaju brze i radikalne promjene uvjetovane razvojem znanosti i utjecajem računalnih tehnologija koje su prisutne u svim razinama ljudskog djelovanja. Stoga društvo treba današnje učenike, odnosno buduće radno aktivne ljude, osposobiti za život i rad u digitalnom okruženju (Kostović-Vranješ, Bulić i Novoselić, 2016). Upravo je to razlog potrebe preusmjeravanja obrazovnog sustava prema razvijanju vještina i kompetencija učenika koje će im pomoći da postanu sposobni, aktivni i odgovorni ljudi koji će osim tradicionalne pismenosti, čitanja i pisanja, imati niz kompetencija koje uključuju neophodnu digitalnu pismenost (EACEA, 2012). Kako bi to bilo moguće izuzetno je važno učenike osposobiti za samostalno učenje, odgovorno djelovanje, donošenje ispravnih odluka u novim i neočekivanim situacijama pa stoga obrazovne politike imaju za cilj povećanje razine obrazovanosti (European Commission, 2010), ali i povećanje profesionalnih kompetentnosti učitelja kao jednog od glavnih činitelja koji utječu na razinu postignuća učenika (Rončević, 2008). Suvremeni učenici žive u digitalnom društvu u kojemu im informacijske i komunikacijske tehnologije (IKT) omogućuju pristup velikoj paleti najrazličitijih informacija te je stoga IKT-u nužno uključivati u odgojno-obrazovni proces i stvarati uvjete za pravilno i uspješno primjenjivanje u svim oblicima učenja. Preduvjet tome je ostvarivanje subjektivnih (imati informacijski i informatički kompetentne učitelje) i objektivnih čimbenika (imati potrebnu infrastrukturu i materijalne uvjete) jer jedan segment sam za sebe ne osigurava implementaciju IKT-e u nastavni proces. Učitelji trebaju biti educirani za osmišljavanje raznovrsnih nastavnih scenarija i primjenu suvremenih IKT-a kojima bi učenicima omogućili stjecanje znanja i razvijanje kompetencija potrebnih za zdrav i održiv život u 21. stoljeću (Kostović-Vranješ i Bulić, 2013). Upravo zbog još uvijek prisutne tradicionalno orijentirane nastave, nedovoljne uporabe IKT-a $i$ 
nužnosti razvijanja digitalne kompetencije učenika učiteljima je potrebno ukazivati na mogućnosti primjene suvremenih tehnologija u nastavnom procesu te ih osposobljavati tijekom stručnih usavršavanja. Istraživanje kompetencija učitelja biologije za izradu računalnih sadržaja (Bulić i Novoselić, 2016) pokazalo je kako učitelji biologije nedovoljno primjenjuju IKT-u u nastavi, a u radu najčešće koriste samo Power Point prezentacije i njihove permutacije.

Primjena IKT-e u obrazovanju dovela je do pojave e-učenja, novog vida učenja koji predstavlja presjek svijeta IKT-e i svijeta obrazovanja (Stankov, 2010). Elektroničko učenje, e-učenje (engl. e-learning) podrazumijeva korištenje multimedije i interneta u sklopu formalnog obrazovanja koji omogućuju pristup udaljenim izvorima i uslugama pomoću suradnje i komunikacije na daljinu. E-učenje karakterizira fizička odvojenost učitelja i učenika, bez postojanja face to face kontakta (f2f), a tim procesom učenik stječe potrebna znanja i vještine (Keegan, 1996). Prednost je ovog tipa učenja njegova otvorenost, a time i cjelodnevna dostupnost, što olakšava učenicima da sami biraju kada, kako i koliko će učiti, kada će komunicirati s učiteljem ili pristupati drugim izvorima znanja koji su važni za određenu temu. Primjena e-učenja, implicira postojanje računalne opreme te digitalne pismenosti učenika $\mathrm{i}$ njihovih učitelja jer su im u protivnom računalni sadržaji beskorisni (Bulić, 2018). Provedena istraživanja o primjeni IKT-e u obrazovanju (UNESCO, 2005; Balanskat i sur. 2007; Hutinski i Aurerer, 2009; Bulić, 2018) ukazuju na važnost integriranja IKT-e u nastavni proces radi pozitivnog i motivirajućeg utjecaja na učenike i njihovo osposobljavanje za život u digitalnom društvu.

Prema American Association for the Advancement of Science (1993) i National Research Council - USA (NRC, 1996) glavni cilj obrazovanja u 21. stoljeću treba biti usmjeren na prirodoslovno opismenjavanje učenika jer prirodoslovno pismen učenik kritički promišlja, interpretira složene podatke i rješava problemske zadatke. Sve je to danas izvedivo upravo uporabom e-učenja koje se temelji na konceptima kao što su samostalno učenje, aktivno učenje, nezavisno učenje, a obuhvaća rješavanje problema, simulacije i praktičan rad. Kako su Osborne, Simon i Collins (2003) ukazali na opadanje interesa učenika prema prirodoslovlju smjer djelovanja obrazovne politike mogao bi biti u iznalaženju motivacijskih faktora učenika za učenje nastavnih predmeta STEM područja. Jedna od mogućnosti je primjena eučenja za koje povećava učenički interes (Bulić, 2018) ali svakako je nužno paziti i na količinu i vremensko trajanje primjene ovoga oblika učenja.

Bez obzira radi li se o tradicionalnoj nastavi ili e-učenju učenici trebaju ostvariti tražene obrazovne ishode nakon procesa učenja. Prijedlogom Nacionalnoga kurikuluma nastavnoga predmeta Priroda (2016) i Prijedlogom Nacionalnoga kurikuluma nastavnoga predmeta Biologija (2016) određeni su svrha, ciljevi, struktura, odgojno-obrazovni ishodi i razine njihove usvojenosti u navedenim nastavnim predmetima. Također je u tim dokumentima istaknuta povezanost s drugim predmetima, odgojnoobrazovnim područjima i međupredmetnim temama te vrednovanje usvojenosti odgojno-obrazovnih ishoda u pojedinom nastavnom predmetu. Makrokoncepti u nastavi Prirode i Biologije su: Energija u živome svijetu, Procesi i međuovisnosti u živome svijetu, Organiziranost živoga svijeta i Prirodoznanstveni pristup. Makrokoncepti imaju različitu širinu i broj obrazovnih ishoda, a u sebi integriraju koncepte nižih razina. Odgojni-obrazovni ishodi predstavljaju jasne i nedvosmislene iskaze očekivanja od učenika u određenom konceptu na kraju određene godine učenja, a podrazumijevaju ono što učenik treba moći učiniti, znati i koje kompetencije odnosno vještine treba posjedovati (Lončar-Vicković i Dolaček-Alduk, 2009). Svaki je pojedini ishod u Prijedlogu Nacionalnoga kurikuluma oblikovan kao cjelina koja ima više komponenti: formulaciju samoga ishoda, razradu ishoda te preporuke za njegovo ostvarivanje uz opis razina usvojenosti. Učitelju je velika pomoć u radu razrada

Broj 4, prosinac 2018. 
ishoda koja uključuje preciznije određenje aktivnosti i sadržaja u okviru pojedinog ishoda ili skupine ishoda što svakako treba imati na umu prilikom planiranja nastavnoga sata. Definiranje obrazovnih ishoda najčešće se temelji na Bloomovoj taksonomiji koja razlikuje tri područja: kognitivno, afektivno i psihomotorno. Kognitivno područje obuhvaća znanja i razumijevanja, afektivno područje odnosi se na stavove i uvjerenja, a psihomotorno područje je područje vještina ili umijeća. Kognitivno područje sastoji se od šest obrazovnih razina: znanje, razumijevanje, primjena, analiza, sinteza i vrjednovanje (Bloom, 1956). U radu u razredu izuzetno je bitno uskladiti metodički scenarij s razinama obrazovnih ishoda koje trebaju biti praćene jasnim kriterijima vrjednovanja, a sve s ciljem utvrđivanja ostvarenosti obrazovnih ishoda. Za svaki ishod učenja treba imati primjer zadatka kojim se provjerava ostvarenost toga ishoda, izbjegavajući već korišteni aktivni glagol. Jedan ishod se može provjeravati i kroz više zadataka. Stoga je učiteljima praktičarima potrebna dodatna edukacija za sastavljanje pitanja i zadataka kojima provjeravaju tražene ishode različitih kognitivnih razina. Kod pisanja ishoda i pitanja ili zadataka za njihovu provjeru učitelj treba koristiti precizne glagole: analizirati, opisati, definirati, napraviti, usporediti, razlikovati, argumentirati, skicirati, nacrtati, a istovremeno izbjegavati neprecizne glagole poput znati, razumjeti, cijeniti, zapamtiti, upoznati, naučiti, osvijestiti (Bloom, 1956). Navedene glagole ne bi se smjelo shvatiti jednoznačno jer ponekad se isti glagol može koristiti za izražavanje ostvarenosti ishoda različite kognitivne razine.

Neovisno o okolnostima u kojima se odvija proces učenja, vrednovanje nalaže da se učenje definira u obliku očekivanih ishoda učenja gdje se već u opisu ishoda može definirati i metoda vrednovanja. Ako je ishod učenja da učenik može napisati esej kojim opisuje nešto, vrednovanje ishoda učenja provodi se metodom vrednovanja pisanja eseja. Neki ishodi učenja ne ukazuju na metodu vrednovanja pa je stoga na učitelju da utvrdi kriterije vrednovanja koji su ponekad i precizniji od samih ishoda učenja (Dragičević i Dželalija, 2016).

Određivanje kognitivnih razina znanja može se odvijati na više načina. Grgin (1999) razlikuje četiri razine kognitivnih postignuća: 1 . znanje - reprodukcija, 2. konceptualno razumijevanje, 3. primjena i 4. rješavanje problema. Crooks (1988) razlikuje samo tri razine: 1. reproduktivno znanje, 2. razumijevanje i primjena te 3 . rješavanje problema. Na stručnim skupovima za učitelje i nastavnike biologije te voditelje županijskih stručnih vijeća u Splitu 2007. učitelji su se opredijelili za korištenje triju razina (prema Crooksu). Prva razina, prema Crooks-u, odnosi se na reproduktivno znanje temeljeno na memoriranju podataka, uz obuhvaćanje i literarnoga razumijevanja (učenik može prepričati neki sadržaj, a da pritom nužno ne dostigne razinu razumijevanja koncepta). Druga razina, razumijevanja i primjene, uključuje konceptualno razumijevanje nastavnih sadržaja koje je osnova trajnoga znanja. Do konceptualnoga razumijevanja dolazi kod primjene stečenih znanja kada se stvaraju veze između novih i postojećih znanja. Povezanost razumijevanja i primjene u nastavi Prirode i Biologije uočava se u situaciji kada učenik provjerava svoje razumijevanje navodeći vlastiti primjer i objašnjavajući ga. Treća razina, rješavanje problema, povezuje više kognitivne razine (analizu, vrjednovanje, stvaranje) Bloomove taksonomije. Matijević (2011) navodi kako znanje u pedagoškom i didaktičkom smislu predstavlja rezultat spoznaje u znanosti i rezultat učenja u i izvan nastave. Gagné (1977, prema Matijević, 2011) razlikuje uz deklarativno znanje, koje se odnosi na reproduktivno znanje, još proceduralno i metakognitivno znanje. Eksponencijalan rast znanja i potreba suvremenog društva za novim kompetencijama učenika zahtijevaju preusmjeravanje obrazovanja s deklarativnog znanja prema dubljem razumijevanju potrebnih bioloških koncepata. Provedena istraživanja pokazuju kako učenici sve biološke koncepte ne razumiju jednako dobro (Lukša, 2011), pojedini nastavni sadržaji nisu 
im interesantni (Garašić, 2012; Bulić, 2018), a provjere znanja kojima su učenici izloženi, ispituju uglavnom samo reproduktivno znanje, tj. prvu kognitivnu razinu. Golubić i sur. (2017) su pokazali kako učenici na natjecanjima iz biologije vrlo uspješno rješavaju zadatke 1. kognitivne razine, a najmanju riješenost su imali zadatci 2 . kognitivne razine.

Istraživanje učinkovitosti e-učenja u odnosu na tradicionalnu nastavu (Bulić i sur., 2017) pokazalo je kako je e-učenje jednako učinkovito kao i tradicionalna nastava u kojoj se koriste suvremene metode rada i kao takvo može biti korišteno u situacijama kada učenici zbog različitih razloga ne mogu prisustvovati nastavi u razredu. Bulić i suradnici (2017) su pokazali kako je statistički značajna razlika kod učenika 5. i 6. razreda koji su napredovali korištenjem e-učenja jer su postigli bolji uspjeh na pisanoj provjeri znanja nakon korištenja e-učenja, a u odnosu na predispit znanja. Za razliku od njih, učenici 7. i 8. razreda nisu statistički značajno napredovali korištenjem e-učenja. Uzroke takvih rezultata dijeli u dvije skupine: one zbog kojih je bolja eksperimentalna skupina drugoga obrazovnog ciklusa od kontrolne i uzroke zbog kojih su ujednačene eksperimentalna i kontrolna skupina trećega obrazovnog ciklusa. Nastavne teme učenika 5. i 6. razreda bile su zanimljivije, učenici su bili više motivirani za rad u prirodoslovlju, poticaj im je bio rad s IKT-om. Učenici trećega obrazovnog ciklusa imali su ujednačene rezultate na koje je mogla utjecati nastava kontrolne skupine koja je bila organizirana u blok satu koristeći suvremene strategije rada, korištenje konceptualnih mapa u obradi i ponavljanju, što je moglo voditi dobroj uspješnosti kontrolne skupine. Negativno se na rezultate učenika 7. i 8. razreda mogao odraziti njihov općeniti pad interesa za učenje prirodoslovlja.

Provedeno istraživanje imalo je za cilj utvrditi hoće li učenici eksperimentalne skupine, koji obrazovne ishode ostvaruju e-učenjem, imati statistički značajno bolje rezultate u odnosu na kontrolnu skupinu, u rješavanju zadataka za provjeru usvojenosti ishoda učenja prema kognitivnim razinama. Očekivalo se kako će učenici eksperimentalne skupine bolje rješavati zadatke druge i treće kognitivne razine. $S$ ciljem istraživanja postavljene hipoteze učenici eksperimentalne $i$ kontrolne skupine su, nakon obrađenih nastavnih cjelina, pisali pisane provjere znanja koje su sadržavale pitanja sve tri kognitivne razine.

\section{METODE}

Prije provedbe istraživanja roditelji učenika potpisali su suglasnost kojom dozvoljavaju sudjelovanje djece u istraživanju. Plan istraživanja uvršten je u Školski kurikulum i odobren od strane Školskog odbora. Provedeno istraživanje obuhvatilo je 162 učenika 5., 6., 7. i 8. razreda osnovne škole (drugi i treći obrazovni ciklus). lako je uzorak ispitanika namjeran, on predstavlja cjelovitu populaciju škole te po svim svojim karakteristikama predstavlja reprezentativan uzorak iz cjelovite populacije učenika osnovnih škola (tablica 1). Od ukupnog broja učenika 5. razreda 39,5\% su djevojčice, a 60,5\% su dječaci, a u 6. razredu je 33,33\% djevojčica i $66,67 \%$ dječaka. U sedmom razredu je $40,9 \%$ djevojčica i 59,09\% dječaka dok je u osmom razredu podjednako djevojčica i dječaka, po $50 \%$.

Tablica 1. Uzorak ispitanika (1. ispitivana cjelina)

\begin{tabular}{|c|c|c|c|}
\hline razred & $\begin{array}{c}\text { eksperimentalna } \\
\text { skupina }\end{array}$ & $\begin{array}{c}\text { kontrolna } \\
\text { skupina }\end{array}$ & $\begin{array}{c}\text { ukupno } \\
\text { učenika }\end{array}$ \\
\hline $\mathbf{5 .}$ & 20 & 18 & 38 \\
\hline $\mathbf{6 .}$ & 23 & 19 & 42 \\
\hline $\mathbf{7 .}$ & 21 & 23 & 44 \\
\hline $\mathbf{8 .}$ & 18 & 20 & 38 \\
\hline ukupno & 82 & 80 & 162 \\
\hline
\end{tabular}




\section{Eksperimentalni postupak}

Prije početka e-učenja učenici svih razrednih odjela bili su podijeljeni na kontrolnu i eksperimentalnu skupinu temeljem predtesta. Nastavni sadržaji koji su postavljeni na platformu otvorenoga koda Moodle (u nastavku Moodle) dizajnirani su korištenjem ADDIE modela oblikovanja nastave. Dizajn nastavnih sadržaja i postavljanje na Moodle trajalo je više mjeseci, a postavljeni su nastavni sadržaji iz istraživanih nastavnih cjelina nastavnih predmeta Prirode (5. i 6. razred) i Biologije (7. i 8. razred). Učenicima eksperimentalne skupine izrađene su lozinke i bili su instruirani 1 školski sat o osnovama rada na Moodle-u. Za vrijeme nastave učenici kontrolne skupine su bili u učionici biologije i radili su s učiteljicom koristeći suvremene metode rada u nastavi dok su učenici eksperimentalne skupine bili u učionici informatike i nisu imali licem u lice (f2f) kontakta $s$ učiteljicom biologije. Učenici eksperimentalne skupine su elektroničkim nastavnim sadržajima, postavljenima na Moodle, pristupali i od kuće kada su i koliko dugo željeli, a učiteljica biologije je mogla pratiti njihovo pristupanje enastavnim sadržajima te je s njima komunicirala isključivo elektroničkim putem (forum, mail, e-poruke, chat).

Pripreme za eksperimentalnu i kontrolnu skupinu bile su jednake u smislu planiranih ciljeva i obrazovnih ishoda te nastavnih aktivnosti za sve učenike, bez obzira radili oni e-učenje ili tradicionalnu nastavu. Planirani su obrazovni ishodi učenja prema važećem Nastavnom planu i programu za osnovnu školu (Nastavni plan i program za osnovnu školu, 2006). Elektronički nastavni sadržaji postavljeni na Moodle bili su jednostavno i pregledno prikazani na korisničkom sučelju (slika 1.) tako da su im učenici lako pristupali i koristili ih. Ukoliko se pojavila nejasnoća kontaktirali su učiteljicu elektroničkim putem.

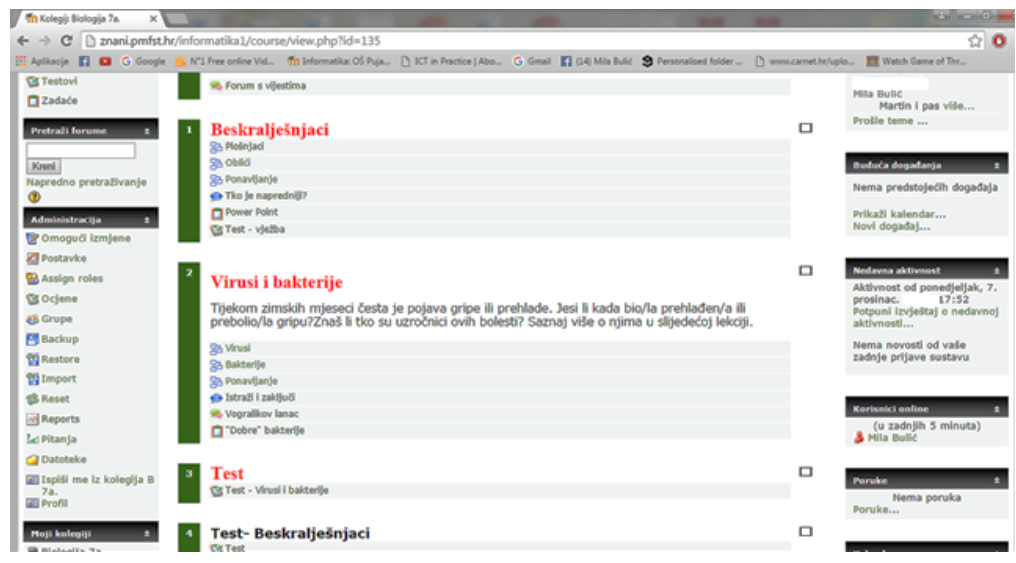

Slika 1. Izgled prve stranice korisničkog sučelja u sustavu Moodle

Kako bi učenici eksperimentalne skupine mogli uspješno samostalno učiti korištenjem Moodle-a, nastavni sadržaji Prirode i Biologije su bili podijeljeni u manje zasebne logičke cjeline imenovane u izborniku Lesson menu na lijevoj strani sučelja. Sadržajima su mogli pristupiti jednostavnim odabirom traženog područja. Tekstualni nastavni sadržaji pojedine nastavne jedinice su bili nadopunjeni različitim vizualnim i audiovizualnim izvorima, fotografijama, ilustracijama, prikazima 3D modela te video zapisima i animacijama. Sve je imalo za cilj pomoći učenicima u ostvarivanju potrebnih ishoda učenja. Svaka nastavna jedinica je na kraju sadržavala dio za ponavljanje i vježbanje, a po završetku cijele nastavne cjeline učenici svakoga razreda su rješavali pisanu provjeru znanja, sastavljenu od pitanja različitih kognitivnih razina. Prednost sustava Moodle bila je u tome što su učenici eksperimentalne skupine odmah mogli vidjeti riješenost pisane provjere znanja, a mogli su i detaljno provjeriti svaki pojedini zadatak. Učenici eksperimentalne skupine su navedenu pisanu provjeru znanja 
pisali u učionici informatike u e-obliku dok su istovremeno učenici kontrolne skupine identičnu pisanu provjeru pisali u učionici biologije (Bulić, 2018).

Kako bi se realiziralo istraživanje i dobili odgovori na postavljene zadatke i hipoteze primijenjeni su instrumenti: predispit znanja, pisana provjera znanja I te pisana provjera znanja II. Instrument predispit znanja poslužio je za generiranje eksperimentalne i kontrolne skupine za svaki pojedini razred. Predispit su pisali svi učenici mjesec dana prije početka rada na sustavu Moodle, a bila su konstruirana četiri različita predispita znanja, za učenike od 5. do 8. razreda.

Učenici su nakon svake nastavne cjeline Prirode ili Biologije pisali pisanu provjeru znanja. Pitanja u provjerama znanja bila su identična za eksperimentalnu i kontrolnu skupinu, ali se razlikovao način izvedbe jer su učenici eksperimentalne skupine provjeru znanja ispunjavali elektronski, u sustavu Moodle, a učenici kontrolne skupine pisanu su provjeru znanja pisali istovremeno u učionici biologije za vrijeme nastavnog sata Prirode ili Biologije. Kako su na Moodle bile postavljene dvije nastavne cjeline za svaki razred učenici su pisali i dvije pisane provjere te je na Moodle postavljeno ukupno 8 pisanih provjera znanja. Zadatci u pisanim provjerama znanja bili su postavljeni na način da ispituju tražene obrazovne ishode tih nastavnih cjelina prema Nastavnom planu i programu za osnovnu školu (2006). Crooks (1988) razlikuje tri razine kognitivnih postignuća i to: 1. razina - reproduktivno znanje, 2. razina - razumijevanje i primjena te 3 . razina - rješavanje problema pa su stoga u navedenim pisanim provjerama znanja bila zastupljena pitanja svih kognitivnih razina. Najviše pitanja bilo je prve kognitivne razine, a najmanje pitanja treće kognitivne razine. Svi subuzorci ispitanika kontrolne i eksperimentalne skupine rješavali su pisanu provjeru znanja I kojom se ispitivala ostvarenost ishoda učenja pomoću pitanja prve, druge i treće kognitivne razine, a struktura bodova pisane provjere znanja I bila je takva da je približno $50 \%$ bodova bio rezultat odgovora na pitanja kojima se ispituje prva kognitivna razina znanja, oko $30 \%$ bodova bio je rezultat odgovora na pitanja kojima se ispituje druga kognitivna razina, a oko $20 \%$ bodova vezano je bilo uz treću kognitivnu razinu znanja. Pitanja i sama pisana provjera znanja I na Moodle-u je označena kao test (slika 1). Učenici eksperimentalne skupine nisu mogli pristupiti pisanoj provjeri prije učenika kontrolne skupine (učiteljica je „otključala“ pisanu provjeru eksperimentalnoj skupini u trenutku kada je kontrolna skupina dobila tiskanu provjeru znanja).

Instrument pisana provjera znanja II sadržavala je zadatke iz druge obrađivane nastavne cjeline za svaki razred, a ukupno su izrađene 4 pisane provjere znanja II. Struktura zadataka i bodova pisane provjere znanja II bila je kao i kod pisane provjere znanja I (tri kognitivne razine zadataka). Za sve promatrane varijable izračunati su deskriptivni statistički parametri, aritmetička sredina i standardna devijacija. Pojedini podatak je promatran kao nekonzistentan s ostalima ukoliko je bio izvan intervala AS $\pm 2 S D$. Korištenjem Kolmogorov-Smirnovljeva testa testiran je normalitet svih varijabli. Kako je KolmogorovSmirnovljevim testom utvrđeno da distribucija podataka ne pokazuje normalnu raspodjelu, primijenjen je neparametrijski Mann Whitney $U$ test za utvrđivanje statističke značajnosti razlikovanja kontrolne i eksperimentalne skupine, u njihovoj uspješnosti rješavanja zadataka za provjeru ishoda učenja prema kognitivnim razinama zadataka.

\section{REZULTATI}

Kako nije bilo moguće zadovoljiti uvjet da svi razredi u svim ispitivanim cjelinama imaju isti broj bodova na određenoj kognitivnoj razini zadataka u pisanoj provjeri, izračunat je postotak uspješnosti rješavanja zadataka pojedine kognitivne razine. U tablicama 2. i 3. nalaze se rezultati deskriptivne 
statistike za kontrolnu i eksperimentalnu skupinu učenika od 5. do 8. razreda u varijabli Pisane provjere znanja te rezultati testiranja normaliteta i Mann-Whitney $\mathrm{U}$ test.

Iz podataka u tablici 2. razvidno je kako se subuzorci ispitanika kontrolne i eksperimentalne skupine statistički značajno ne razlikuju u rješavanju zadataka prema kognitivnim razinama. Podatci ukazuju kako učenici eksperimentalne i kontrolne skupine jednako dobro ili loše rješavaju zadatke prve, druge i treće kognitivne razine. Premda nije utvrđena statistički značajna razlika, važno je promotriti njihove rezultate u apsolutnim vrijednostima, tj. iz pokazatelja deskriptive statistike. Kod učenika petoga razreda eksperimentalna skupina postigla je bolje rezultate rješavajući zadatke druge ( $A S=90,00)$ i treće $(A S=78,95)$ kognitivne razine u odnosu na kontrolnu skupinu (druga razina, $A S=82,63$; treća razina, $A S=67,11)$. Učenici eksperimentalne skupine šestoga razreda bolje su riješili zadatke prve $(A S=81,14) i$ treće $(A S=76,19)$ kognitivne razine u odnosu na zadatke druge kognitivne razine koje je bolje riješila kontrolna skupina $(A S=83,33)$. Negativan koeficijent asimetričnosti ukazuje na grupiranje podataka prema većim vrijednostima, što znači da su svi učenici bili vrlo uspješni u rješavanju zadataka, odnosno Gaussova je krivulja blago nakrivljena udesno. Maksimalna vrijednost na svim kognitivnim razinama, $u$ oba razreda, i kod kontrolne i kod eksperimentalne skupine, konzistentna je i iznosila je 100, što znači da i u 5. i u 6. razredu u obje skupine postoje učenici koji su $100 \%$ točno riješili test. Minimalne vrijednosti pokazuju kako su $0 \%$ postigli učenici 5 . i 6 . razreda, ali na zadatcima druge ili treće kognitivne razine. Nitko nije postigao $0 \%$ na zadatcima prve kognitivne razine.

Tablica 2. Rezultati deskriptivne statistike za kontrolnu i eksperimentalnu skupinu učenika 5. i 6. razreda u varijabli Pisane provjere znanja $\left(\mathrm{K}_{1}{ }^{\mathrm{K}}\right.$ - kondenzirani rezultati kognitivne razine 1 , kontrolna skupina; $\mathrm{K}_{1} \mathrm{E}$ - kondenzirani rezultati kognitivne razine 1 , eksperimentalna skupina; $\mathrm{K}_{2}{ }^{\mathrm{E}}$ - kondenzirani rezultati kognitivne razine 2, eksperimentalna skupina; $\mathrm{K}_{2}{ }^{\mathrm{K}}$-kondenzirani rezultati kognitivne razine 2, eksperimentalna skupina; $\mathrm{K}_{3}{ }^{\mathrm{E}}$ - kondenzirani rezultati kognitivne razine 3, eksperimentalna skupina; $\mathrm{K}_{3} \mathrm{~K}^{\mathrm{k}}$ - kondenzirani rezultati kognitivne razine 3 , kontrolna skupina)

\begin{tabular}{|c|c|c|c|c|c|c|c|c|c|c|c|c|c|}
\hline & & \multicolumn{7}{|c|}{ parametri deskriptivne statistike } & \multicolumn{2}{|c|}{ K-S test } & \multicolumn{3}{|c|}{ Mann-Whitney U test } \\
\hline razred & & AS & SD & $M$ & $\min$ & $\max$ & $\alpha_{3}$ & $\alpha_{4}$ & $\begin{array}{c}D \\
\max \end{array}$ & K-S p & u & z & $p$ \\
\hline \multirow{6}{*}{5.} & $\mathrm{~K}_{1}{ }^{\mathrm{K}}$ & 81,08 & 14,78 & 82,58 & 50,0 & 100,00 & $-0,33$ & $-0,94$ & 0,14 & $>0,20$ & \multirow{2}{*}{720,00} & \multirow{2}{*}{0,02} & \multirow{2}{*}{0,99} \\
\hline & $\mathrm{K}_{1} \mathrm{E}$ & 80,10 & 17,71 & 83,33 & 16,67 & 100,00 & $-1,55$ & 3,34 & 0,17 & $>0,20$ & & & \\
\hline & $\mathrm{K}_{2}{ }^{\mathrm{K}}$ & 82,63 & 24,24 & 100,00 & 20,00 & 100,00 & $-1,32$ & 0,76 & 0,32 & $<0,01$ & \multirow{2}{*}{583,50} & \multirow{2}{*}{1,43} & \multirow{2}{*}{0,15} \\
\hline & $\mathrm{K}_{2}{ }^{\mathrm{E}}$ & 90,00 & 23,60 & 100,00 & 20,00 & 100,00 & $-1,41$ & 1,65 & 0,35 & $<0,01$ & & & \\
\hline & $\mathrm{K}_{3} \mathrm{~K}$ & 67,11 & 32,42 & 66,67 & 0,00 & 100,00 & $-0,48$ & $-1,01$ & 0,24 & $<0,05$ & \multirow{2}{*}{573,50} & \multirow[b]{2}{*}{1,54} & \multirow{2}{*}{0,12} \\
\hline & $\mathrm{K}_{3} \mathrm{E}$ & 78,95 & 26,69 & 100,00 & 0,00 & 100,00 & $-1,00$ & 0,29 & 0,34 & $<0,01$ & & & \\
\hline \multirow{6}{*}{6.} & $\mathrm{~K}_{1}{ }^{\mathrm{K}}$ & 77,29 & 18,29 & 84,62 & 30,77 & 100,00 & $-0,71$ & $-0,18$ & 0,20 & $<0,10$ & \multirow{2}{*}{730,50} & \multirow{2}{*}{1,35} & \multirow{2}{*}{0,18} \\
\hline & $\mathrm{K}_{1} \mathrm{E}$ & 81,14 & 21,50 & 84,62 & 30,77 & 100,00 & $-0,87$ & $-0,42$ & 0,24 & $<0,05$ & & & \\
\hline & $\mathrm{K}_{2}{ }^{\mathrm{K}}$ & 83,33 & 22,05 & 100,00 & 40,00 & 100,00 & $-0,92$ & $-0,66$ & 0,35 & $<0,01$ & \multirow{2}{*}{726,50} & \multirow{2}{*}{$-1,39$} & \multirow{2}{*}{0,17} \\
\hline & $\mathrm{K}_{2}{ }^{\mathrm{E}}$ & 80,48 & 16,22 & 80,00 & 20,00 & 100,00 & $-1,48$ & 4,19 & 0,35 & $<0,01$ & & & \\
\hline & $\mathrm{K}_{3}{ }^{\mathrm{K}}$ & 70,24 & 41,41 & 100,00 & 0,00 & 100,00 & $-0,90$ & $-0,92$ & 0,38 & $<0,01$ & \multirow{2}{*}{799,50} & \multirow{2}{*}{0,73} & \multirow{2}{*}{0,46} \\
\hline & $\mathrm{K}_{3} \mathrm{E}$ & 76,19 & 41,67 & 100,00 & 0,00 & 100,00 & $-1,27$ & $-0,29$ & 0,45 & $<0,01$ & & & \\
\hline
\end{tabular}

(AS-aritmetička sredina; med -položajna sredina; min-minimalna vrijednost; max-maksimalna vrijednost; SD-standardna devijacija; $\alpha_{3}$ koeficijent asimetričnosti Skewness; $\alpha_{4}$-koeficijent spljoštenosti Kurtosis)

Iz podataka u tablici 3. uočava se kako se subuzorci ispitanika (kontrolna i eksperimentalna skupina) 7. i 8. razreda također statistički značajno ne razlikuju u rješavanju zadataka prema kognitivnim razinama. Rezultati jasno pokazuju kako je kod učenika 7. razreda rješavanje prve kognitivne razine gotovo značajno, a iz deskripcijske analize vidljivo je kako je kontrolna skupina riješila 78,64\% zadataka prve kognitivne razine dok je eksperimentalna skupina riješila 72,28\%. Kontrolna skupina 7. razreda bolje je riješila zadatke na svim kognitivnim razinama u odnosu na eksperimentalnu. Iz tablice 3 . vidljivo je kako učenici kontrolne skupine 8. razreda rješavaju u prosjeku $68,06 \%$ zadataka prve kognitivne razine dok istovremeno njihova eksperimentalna skupina rješava prosječno $71,34 \%$ zadataka prve kognitivne razine. lako eksperimentalna skupina rješava bolje zadatke ove razine, to nije statistički značajno. 
Promatrajući riješenost zadataka druge kognitivne razine gotovo da nema razlike između eksperimentalne i kontrolne skupine 8. razreda ( $A S=61,45 ; A S=61,97)$. Eksperimentalna skupina 8. razreda neznatno lošije $(A S=67,11)$ riješila je zadatke treće kognitivne razine naspram kontrolne skupine ( $A S=72,37)$. Učenici 8 . razreda najlošije su riješili zadatke druge kognitivne razine, neovisno jesu li bili eksperimentalna ili kontrolna skupina. Tako niska riješenost ovih zadataka ukazuje na konceptualno nerazumijevanje prethodno izvedenih praktičnih radova na kojima su se temeljili zadatci iz pisane provjere. Maksimalna vrijednost na svim kognitivnim razinama, u svim razredima, i kod kontrolne $\mathrm{i}$ kod eksperimentalne skupine konzistentna je $\mathrm{i}$ iznosila je 100, što znači da u eksperimentalnoj i kontrolnoj skupini postoje učenici koji su $100 \%$ točno riješili test. Minimalne vrijednosti pokazuju kako kod kontrolne skupine $0 \%$ su postigli učenici u 7. i 8.razreda, ali na zadatcima druge i treće kognitivne razine (isto kao i učenici 5. i 6 . razreda). Nitko nije postigao $0 \%$ na zadatcima prve kognitivne razine. To može ukazivati kako su učenicima uistinu najlakši zadatci prve kognitivne razine kojima se ispituje osnovno činjenično znanje. Najniži minimalan postotak na zadatcima prve kognitivne razine postižu učenici 8. razreda (min=15,38\%). Dobiveni rezultati pokazuju kako eksperimentalna skupina nije bila statistički značajno bolja u rješavanju zadataka na drugoj i trećoj kognitivnoj razini u odnosu na kontrolnu već učenici neovisno o skupini jednako uspješno/neuspješno rješavaju zadatke.

Tablica 3. Rezultati deskriptivne statistike za kontrolnu i eksperimentalnu skupinu učenika od 7. i 8. razreda u varijabli Pisane provjere znanja ( $\mathrm{K}_{1}{ }^{\mathrm{K}}$ - kondenzirani rezultati kognitivne razine 1 , kontrolna skupina; $\mathrm{K}_{1} \mathrm{E}^{\mathrm{B}}$ - kondenzirani rezultati kognitivne razine 1 , eksperimentalna skupina; $\mathrm{K}_{2}{ }^{\mathrm{E}}$ - kondenzirani rezultati kognitivne razine 2, eksperimentalna skupina; $\mathrm{K}_{2}{ }^{\mathrm{K}}-$ kondenzirani rezultati kognitivne razine 2, eksperimentalna skupina; $\mathrm{K}_{3}{ }^{\mathrm{E}}-\mathrm{k}$ ondenzirani rezultati kognitivne razine 3, eksperimentalna skupina; $\mathrm{K}_{3}{ }^{\mathrm{K}}$ - kondenzirani rezultati kognitivne razine 3 , kontrolna skupina)

\begin{tabular}{|c|c|c|c|c|c|c|c|c|c|c|c|c|c|}
\hline \multirow[b]{2}{*}{ raz } & & \multicolumn{7}{|c|}{ parametri deskriptivne statistike } & \multicolumn{2}{|c|}{ K-S test } & \multicolumn{3}{|c|}{ Mann-Whitney U test } \\
\hline & & AS & SD & M & $\min$ & $\max$ & $\alpha_{3}$ & $\alpha_{4}$ & $\begin{array}{c}\mathrm{D} \\
\max \end{array}$ & $\mathrm{K}-\mathrm{S} p$ & 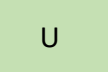 & Z & $p$ \\
\hline \multirow{6}{*}{7.} & $\mathrm{~K}_{1}{ }^{\mathrm{K}}$ & 78,64 & 19,05 & 80,00 & 43 & 100,00 & $-0,72$ & 0,21 & 0,14 & $>0,20$ & \multirow{2}{*}{744,50} & \multirow{2}{*}{$-1,86$} & \multirow{2}{*}{0,06} \\
\hline & $\mathrm{K}_{1} \mathrm{E}^{2}$ & 72,28 & 16,30 & 73,30 & 35,71 & 100,00 & $-0,08$ & $-0,79$ & 0,09 & $>0,20$ & & & \\
\hline & $\mathrm{K}_{2}{ }^{\mathrm{K}}$ & 71,21 & 44,08 & 100,00 & 0,00 & 100,00 & $-0,96$ & $-1,04$ & 0,42 & $<0,01$ & \multirow{2}{*}{879,50} & \multirow{2}{*}{$-0,73$} & \multirow{2}{*}{0,46} \\
\hline & $\mathrm{K}_{2} \mathrm{E}^{2}$ & 66,29 & 41,99 & 100,00 & 0,00 & 100,00 & $-0,70$ & $-1,25$ & 0,33 & $<0,01$ & & & \\
\hline & $\mathrm{K}_{3}{ }^{\mathrm{K}}$ & 75,00 & 40,11 & 100,00 & 0,00 & 100,00 & $-1,10$ & $-0,62$ & 0,44 & $<0,01$ & \multirow{2}{*}{841,50} & \multirow{2}{*}{$-1,05$} & \multirow{2}{*}{0,29} \\
\hline & $\mathrm{K}_{3}{ }^{\mathrm{E}}$ & 67,42 & 38,37 & 100,00 & 0,00 & 100,00 & $-0,62$ & $-1,21$ & 0,32 & $<0,01$ & & & \\
\hline \multirow{6}{*}{8.} & $\mathrm{~K}_{1}{ }^{\mathrm{K}}$ & 68,06 & 20,20 & 71,43 & 15,38 & 100,00 & $-0,69$ & $-0,22$ & 0,14 & $>0,20$ & \multirow{2}{*}{652,00} & \multirow{2}{*}{0,72} & \multirow{2}{*}{0,47} \\
\hline & $\mathrm{K}_{1} \mathrm{E}^{-}$ & 71,34 & 18,77 & 71,43 & 28,57 & 100,00 & $-0,66$ & $-0,23$ & 0,13 & $>0,20$ & & & \\
\hline & $\mathrm{K}_{2}{ }^{\mathrm{K}}$ & 61,45 & 26,20 & 60,00 & 0,00 & 100,00 & $-0,13$ & $-0,50$ & 0,15 & $>0,20$ & \multirow{2}{*}{703,00} & \multirow{2}{*}{0,19} & \multirow{2}{*}{0,85} \\
\hline & $\mathrm{K}_{2}{ }^{\mathrm{E}}$ & 61,97 & 29,70 & 67,50 & 0,00 & 100,00 & $-0,42$ & $-0,75$ & 0,17 & $>0,20$ & & & \\
\hline & $\mathrm{K}_{3}{ }^{\mathrm{K}}$ & 72,37 & 34,28 & 100,00 & 0,00 & 100,00 & $-0,86$ & $-0,38$ & 0,34 & $<0,01$ & \multirow{2}{*}{645,50} & \multirow{2}{*}{$-0,79$} & \multirow{2}{*}{0,43} \\
\hline & $\mathrm{K}_{3}{ }^{\mathrm{E}}$ & 67,11 & 31,36 & 50,00 & 0,00 & 100,00 & $-0,40$ & $-0,59$ & 0,29 & $<0,01$ & & & \\
\hline
\end{tabular}

\section{RASPRAVA}

Uzrok ovakvim rezultatima može biti trenutni način poučavanja u hrvatskim osnovnim školama koji zahtijeva reproduktivno znanje, a koje se tek povremeno konceptualno izgrađuje na višim kognitivnim razinama. Može se reći kako učenici u školama općenito nisu navikli da se od njih traži primjena znanja, a pisane provjere su najčešće sastavljene samo od zadataka prve kognitivne razine. Za rješavanje takvih zadataka učenicima je dovoljno samo puko memoriranje činjenica, u što uopće ne mora biti uključeno i razumijevanje sadržaja.

Kako su učenici svih razreda u eksperimentalnoj i kontrolnoj skupini podjednako uspješno rješavali sve kognitivne razine (nema statistički značajne razlike među njima) razlog može biti i nastavni scenarij učiteljice Prirode i Biologije koja je tražila jednako aktivan angažman učenika kontrolne i eksperimentalne skupine neovisno rade li e-učenje ili tradicionalnu nastavu. Učenici eksperimentalne 
skupine sve su provedene pokuse na satu imali snimljene i postavljene na Moodle, a učiteljica je tražila povratne informacije o njihovom razumijevanju. Navedeni rezultati mogu ići u prilog primjeni e-učenja u nastavnom procesu jer pokazuju kako učenici koji koriste e-učenje mogu biti podjednako uspješni kao i učenici u tradicionalnoj nastavi.

Begić i sur. (2016) naglašavaju kako su razvoj metodike nastave biologije i potreba konceptualnog razumijevanja nastavnih sadržaja potaknuli autore na usuglašavanje kriterija za oblikovanje zadataka i konstrukciju pisanih testova za natjecanja iz biologije, ali i za primjenu u pisanoj provjeri znanja tijekom redovne nastave (Radanović i sur, 2013). Prema Radanović i sur. (2010) nastavnici biologije u Republici Hrvatskoj dogovorno su prihvatili podjelu na tri kognitivne razine prema Crooks-u. Radanović i sur. (2013) iznijeli su preporuke strukture pisane provjere znanja za sve vrste natjecanja i to za školsko natjecanje $40 \%$ zadataka prve kognitivne razine, $50 \%$ zadataka druge kognitivne razine i $10 \%$ zadataka treće kognitivne razine, s tim da u daljnjem natjecanju preporučuju smanjivanja udjela zadataka prve kognitivne razine. Ovdje izneseni rezultati prikazuju istraživanje koje je bilo dijelom redovne nastave i nije imalo natjecateljski karakter. Struktura pisane provjere znanja bila je takva da je, iako su u pitanjima bile zastupljene sve kognitivne razine, među njima bilo najviše pitanja prve kognitivne razine. Kako učenici nisu do tada navikli na rješavanje zadataka viših kognitivnih razina pazilo se na njihov omjer. Kod osmišljavanja pisanih provjera znanja u svakodnevnom radu u razredu također je potrebno paziti na odnose broja pitanja pojedinih kognitivnih razina u testu i postotak njihove zastupljenosti. I druga istraživanja (Begić i sur, 2016) također pokazuju kako učenici najbolje rješavaju zadatke 1. kognitivne razine. Ti rezultati koreliraju s rezultatima u prikazanom istraživanju jer nitko nije imao $0 \%$ na zadatcima prve kognitivne razine.

Vrednovanje svih kognitivnih razina znanja nije uvijek jednostavno. Najlakše je vrednovati reproduktivno, a teže ono povezano $s$ razumijevanjem i praktičnom primjenom. Sami učenici su nenaviknuti na pisane provjere u kojima su pitanja koja provjeravaju i više razine kognitivnih sposobnosti. Upravo stoga se pri kreiranju istraživanja pazilo na omjer zadataka pojedine razine $u$ pisanoj provjeri. Sve upućuje na to kako s učenicima treba raditi na boljem konceptualnom razumijevanju nastavnih sadržaja te uvoditi u nastavu i pitanja viših kognitivnih razina koja traže dublje razumijevanje i primjenu naučenoga. I ovo istraživanje je, sukladno istraživanju Golubić i sur. (2017) pokazalo kako učenici bolje (iako ne statistički značajno) rješavaju zadatke prve kognitivne razine za koje nije potrebno konceptualno razumijevanje nastavnih sadržaja. Više kognitivne razine zadataka bile su riješene posebno kod onih zadataka gdje je za dio zadatka bilo dostatno imati potrebno činjenično znanje, a u ostatku su se učenici možada služili eliminacijom i logičnim zaključivanjem.

Latin i sur. (2016) ističu kako učeniku u formiranju vlastitog znanja može pomoći kreiranje konceptualnih mapa jer tijekom njihova kreiranja učenik samostalno uči, kritički razmišlja i donosi određene odluke, a nakon toga procesa učenici imaju veću uspješnost u rješavanju zadataka viših kognitivnih razina u odnosu na učenike koji su poučavani frontalnim oblikom rada i nisu koristili izradu koncept mapa. I drugi autori potvrđuju kako učenici koji uče aktivnim metodama rada duže zadržavaju stvorene koncepte u odnosu na učenike koji su pasivni sudionici nastavnog procesa (Allen i Tanner, 2006; Modell, 1996; Smith i sur, 2005, prema Latin, 2016). Upravo navedeno daje temelj objašnjenju uspješnog rješavanja pisane provjere znanja od strane kontrolne skupine svih razreda jer je učiteljica $s$ učenicima kontrolne skupine na satu Prirode i Biologije koristila aktivne oblike rada koji su tražili da učenik bude aktivan sudionik nastavnog procesa, a ne pasivan slušač, a učenici su svakoga razreda nakon obrađivanih nastavnih cjelina rješavali koncept mape koje su imali u svojim radnim bilježnicama.

Broj 4, prosinac 2018. 
Navedeni učenici su radom na konceptualnim mapama koje su bile već otisnute u radnim bilježnicama, ili samostalnim kreiranjem novih, bili uspješniji u prepoznavanju veza među potrebnim konceptima i rješavanju zadataka viših kognitivnih razina. Vjerojatno je to jedan od čimbenika koji je doveo do ujednačenosti rezultata eksperimentalne i kontrolne skupine te se može reći da se e-učenje pokazalo jednako uspješnim kao suvremena nastava koja koristi suvremene metode i strategije rada te navedeno može ići u prilog većoj uporabi e-učenja u nastavi Prirode i Biologije. Stoga je važno u nastavnom procesu koristiti sve raspoložive strategije koje će voditi konceptualnom razumijevanju nastavnih sadržaja te stjecanju trajnog i primjenjivog znanja.

\section{ZAKLUČAK I METODIČKI ZNAČAJ}

Rezultati pokazuju kako učenici neovisno o tome koriste li u radu e-učenje ili tradicionalnu nastavu jednako uspješno rješavaju zadatke prve, druge i treće kognitivne razine. Rezultati istraživanja bi svako trebali biti putokaz obrazovnoj politici prema preoblikovanju inicijalnog obrazovanja budućih učitelja biologije te smjernica za potrebno dodatno profesionalno usavršavanje učitelja praktičara. Usavršavanje učitelja praktičara trebalo bi ići u smjeru jačanja njihovih digitalnih kompetencija jer će tako biti spremniji implementirati e-učenje u nastavu. S učiteljima praktičarima dodatno bi trebalo raditi i na vještini oblikovanja pitanja svih kognitivnih razina kojima ispituju tražene obrazovne ishode.

Metodički značaj provedenoga istraživanja ogleda se u rezultatima koji pokazuju kako učenici jednako uspješno ili neuspješno rješavaju zadatke različitih kognitivnih razina. Upravo stoga, neovisno o tome rješavaju li učenici bolje zadatke viših kognitivnih razina potrebno je provjeravati i njihovo konceptualno razumijevanje, posebno ako je rješenje zadatka viših razina bilo samo zaokruživanje ponuđenoga odgovora. Stoga je potrebno nastavu Prirode i Biologije preusmjeravati prema konceptualnom razumijevanju traženih makro i mikrokoncepata te onda i postavljanju dobro osmišljenih pitanja i zadataka svih kognitivnih razina u pisane provjere znanja.

\section{LITERATURA}

Begić, V., Bastić, M., Radanović, I. 2016. Utjecaj biološkog znanja učenika na rješavanje zadataka viših kognitivnih razina. Educ. biol., 2:13-42.

Bloom, B. S. 1956. Taxonomy of Educational Objectivas, Handbook I: The Cognative Domain. New York: David McKay Co., Inc. Bulić, M. 2018. Sustavi e-učenja u promicanju obrazovanja za zdrav i održiv život, doktorska disertacija. Prirodoslovnomatematički fakultet Sveučilišta u Splitu. 2018.

Bulić, M., Jelaska, I. i Mandić Jelaska, P. 2017. Utjecaj e-učenja na usvojenost ishoda učenja u nastavi Prirode i Biologije. Croatian Journal of Education, 19 (2), 447-477. https://doi.org/10.15516/cje.v19i2.2230

Bulić, M. i Novoselić, D. 2016. Kompetencije učitelja biologije za izradu računalnih sadržaja i uporabu informacijskokomunikacijskih tehnologija. Magistra ladertina, 11. (1.), 89-104. Preuzeto s https://hrcak.srce.hr/177643

Crooks, T.J. 1988. Ime Impact of Classroom Evaluation Practice on Students. Review of Educational research, 58(4):438-481. Dragičević, T., Dželalija, M. 2016. Kako napisati ishode učenja?. Prirodoslovno-matematički fakultet, Split.

Europska Komisija/EACEA/ Eurydice, 2012. Developing Key Competences at School in Europe: Challenges and Opportunities for Policy. Eurydice Report, Luksemburg: Ured za publikacije Europske unije.

Garašić, D. 2012. Primjerenost biološkog obrazovanja tijekom osnovnog i gimnazijskog školovanja. Doktorska disertacija, Sveučilište u Zagrebu, Prirodoslovno-matematički fakultet.

Golubić, M., Begić, V., Lukša, Ž., Korać, P., Radanović, I. 2017. Razumijevanje životnog ciklusa i oplodnje tijekom učenja biologije u osnovnoj školi. Educatio biologiae 3, 1, 76-99.

Grgin, T. 1999. Školsko ocjenjivanje znanja. Jastrebarsko: Naklada Slap

Keegan, D. 1996. Foundations of distance education. Psychology Press.

Kostović-Vranješ, V., Bulić, M. 2013. Izobraževanje za zdrav in trajnostni svet. U: Duh, M. (ur.), Okoljsko izobraževanje za 21. stoletje. RIS Dvorec Rakičan, Univerza v Mariboru Pedagoška fakulteta.

Kostović-Vranješ, V., Bulić, M. i Novoselić, D. 2016. Kompetencije učitelja biologije za primjenu informacijsko-komunikacijskih tehnologija u nastavnom procesu. Zbornik radova Filozofskog fakulteta u Splitu, (6-7), 24-43. 
Latin, K., Merdić, E., Labak, I. 2016. Usvojenost nastavnog sadržaja iz biologije primjenom konceptualnih mapa kod učenika srednje škole. Educ. biol. 2,1-9.

Lončar-Vicković, S., Dolaček-Alduk, Z. 2009. Vodič kroz ishode učenja na Sveučilištu J. J. Strosmayera u Osijeku. Osijek: Sveučilište J.J. Strossmayera.

Nacionalni kurikulum nastavnoga predmeta biologija, prijedlog. 2016. Zagreb: Ministarstvo znanosti, obrazovanja i sporta Republike Hrvatske.

Nacionalni kurikulum nastavnoga predmeta priroda, prijedlog. 2016. Zagreb: Ministarstvo znanosti, obrazovanja i sporta Republike Hrvatske.

Nastavni plan i program za osnovnu školu, 2006. Zagreb: Ministarstvo znanosti, obrazovanja i sporta Republike Hrvatske.

National Researsch Council 1996. National Science education standards. Washington, DC, 1996.

Osborne, J., Simon, S. \& Collins, S. 2003. Attitudes towards science: a review of the literature and its implications. International Journal of Science Education, 25(9), 1049 - 1079.

Radanović I., Bastić M., Begić V., Kapov S., Mustać A., Sumpor D. 2013. Preporuke za autore i recenzente testova natjecanja u znanju biologije. HBD.

Stankov, S. 2010. Inteligentni tutorski sustavi: teorija i primjena. Intelligent tutoring systems: theory and practice, Split, PMF Split, 4-43. 